\title{
Localization and function of the IdiA homologue SIr1295 in the cyanobacterium Synechocystis sp. strain PCC 6803
}

\author{
Jörg Tölle, ${ }^{1}$ Klaus-Peter Michel, ${ }^{1}$ Jochen Kruip, ${ }^{3}$ Uwe Kahmann, ${ }^{2}$ \\ Angelika Preisfeld ${ }^{2}$ and Elfriede K. Pistorius ${ }^{1}$
}
1,2 Biologie VIII: Zellphysiologie ${ }^{1}$ and Biologie 12: Morphologie der Pflanzen und Feinbau der Zelle, Universität Bielefeld, D-33501 Bielefeld, Germany
3 Lehrstuhl für Biochemie der Pflanzen, Ruhr- Universität, D-44780 Bochum, Germany

\author{
Author for correspondence: Elfriede K. Pistorius. Tel: +49521 1065601. Fax: +49521 1066410 \\ e-mail: e.pistorius@biologie.uni-bielefeld.de
}

\begin{abstract}
SIr1295 (and SIr0513) in the cyanobacterium Synechocystis sp. PCC 6803 has amino acid similarity to the bacterial FbpA protein family and also to IdiA of Synechococcus PCC 6301/PCC 7942. To determine whether SIr1295 is the periplasm-located component of an iron transporter, or has a function in protecting photosystem (PS) II, subcellular localization and $\Delta$ sIr1295 mutant characterization studies were performed. Localization of SIr1295 provided evidence that it has an intracellular function, since virtually no SIr1295 was detected in the soluble protein fraction of the periplasm or in the cytoplasmic membrane. Characterization of a $\Delta s / r 1295$ Synechocystis PCC 6803 mutant indicated that PS II is more susceptible to inactivation in the mutant than in the wild-type (WT). Under mild iron limitation, modification of PS I to the PS I-IsiA complex is more advanced in the $\Delta$ sIr1295 mutant, indicating that iron deficiency leads more rapidly to changes in the photosynthetic apparatus in the mutant than in the WT. Biochemical fractionation procedures provide evidence that SIr1295 co-purifies with PS II. These results suggest a function of SIr1295 that is comparable to the function of IdiA in Synechococcus PCC $6301 /$ PCC 7942 being a protein that protects PS II under iron limitation in an as yet unknown way.
\end{abstract}

Keywords: Synechocystis PCC 6803, iron deficiency, Slr1295, photosystem I and II

\section{INTRODUCTION}

In a number of previous publications we have shown that under iron-limiting growth conditions a protein of $35 \mathrm{kDa}$, called IdiA (iron deficiency induced protein $\underline{\mathrm{A}}$ ), becomes expressed in highly elevated amounts in the cyanobacteria Synechococcus PCC 6301 and PCC 7942 (accession numbers of idiA from PCC 6301 and PCC 7942 are Z48754 and AJ319672, respectively) as well as in the thermophilic Synechococcus elongatus (Michel et al., 1996, 1998, 1999). IdiA is located almost entirely intracellularly and is mainly associated with the thylakoid membranes (Michel et al., 1998). Comparative investigations about the function of IdiA in Synechococcus PCC 7942 wild-type (WT) and the corresponding IdiA-free mutant indicated that IdiA seems to pref-

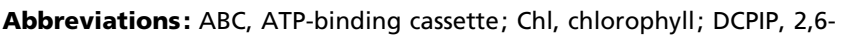
dichlorophenol-indophenol; Dig, digoxigenin; MV, methylviologen; $\mathrm{PBQ}$, phenyl-p-benzoquinone; PCV, packed cell volume; PS I and PS II, photosystem I and II. erentially protect the acceptor side of photosystem II (PS II) under oxidative stress - especially when oxidative stress is caused by iron deficiency (Michel et al., 1996; Exss-Sonne et al., 2000). However, the exact nature of the PS II protecting function of IdiA has remained unclear. Recently, the iron-responsive idiA promoter was characterized and IdiB, with strong similarity to helix-turn-helix transcription factors of the FNR/CAP family, was identified as a positively acting transcription factor of IdiA expression in Synechococcus PCC 7942 (Michel et al., 2001).

The association of IdiA with the thylakoid membranes of Synechococcus PCC 7942/PCC 6301 and the protective function on PS II came somewhat as a surprise, because IdiA has high similarity to the FbpA (also called SfuA) protein of pathogenic bacteria, such as Serratia marcescens (Angerer et al., 1990), Neisseria gonorrhoeae (Berish et al., 1990a; Forng et al., 1997), Neisseria meningitidis (Berish et al., 1990b) and Pasteurella haemolytica (Kirby et al., 1998) for example. FbpA 
belongs to the cluster 1 group of extracellular solutebinding proteins with specificity for ferric iron (Tam \& Saier, 1993). The FbpA protein of pathogenic bacteria is a component of a typical ATP-binding cassette (ABC) transporter for ferric iron across the inner membrane when iron is delivered as $\mathrm{Fe}^{3+}$-transferrin and/or $\mathrm{Fe}^{3+}$ lactoferrin. In the Fbp transport system FbpA is the periplasm-located component, $\mathrm{FbpB}$ is a cytoplasmic membrane protein and $\mathrm{FbpC}$ is a membrane-bound protein carrying a nucleotide-binding motif (Mietzner \& Morse, 1994; Adhikari et al., 1996). A dendrogram was compiled for the pathogenic bacterial FbpA proteins, including the IdiA protein from Synechococcus PCC 6301, showing that IdiA has the highest similarity to FbpA from Pasteurella haemolytica (Kirby et al., 1998).

Recently, a protein immunologically related to IdiA from Synechococcus PCC 6301/PCC 7942 was detected in three marine cyanobacterial species: Synechococcus sp., Crocosphaera sp. and Trichodesmium sp. (Webb et al., 2001). In the cyanobacterium Synechocystis PCC 6803, whose genome has been completely sequenced (Kaneko et al., 1996), there are two genes encoding proteins Slr0513 and Slr1295 which both have high similarity to IdiA from Synechococcus PCC 6301 and PCC 7942 (Slr1295, 53\% identity and 69\% similarity; Slr0513, 51\% identity and $66 \%$ similarity). In addition, a third gene encoding a protein with lower similarity is present: S110237, with $26 \%$ identity and $42 \%$ similarity to IdiA. In a search for genes/proteins involved in iron acquisition in Synechocystis PCC 6803, Katoh et al. (2000, 2001a, b) recently investigated a number of genes encoding polypeptides with similarity to proteins of ABC-type ferric iron transporters. These genes are slr1295, slr0513, slr0327 and sll1878, which were designated futA1, futA2, futB and $f u t C$, respectively. These genes are not located in an operon as is the case for the bacterial iron transporters (for a comparative listing, see Webb et al., 2001). Inactivation of futB or futC or of both futA1 and futA2 greatly reduces the activity of ferric iron uptake and also growth. This group (Katoh et al., 2001a) concludes that the Fut system in Synechocystis PCC 6803 is related to the Sfu/Fbp family of bacterial iron transporters (Adhikari et al., 1996). In the Synechocystis PCC 6803 transport system, proteins FutA1 (Slr1295) and FutA2 (Slr0513) are suggested to be the periplasm-located components which are assumed to play a role in iron binding. This is supported by the recent finding that the GST-tagged recombinant FutA1 was shown to bind ferric ion with high affinity (Katoh et al., 2001b). Since FutA1 and FutA2 are suggested to have redundant or overlapping substrate-binding functions, the phenotype with significantly reduced ferric iron uptake and consequently reduced growth is only obtained in the Synechocystis PCC 6803 double mutant lacking both proteins (Katoh et al., 2001a, b). In agreement with the assumed function of Slr0513 (FutA2) are the data of Fulda et al. (2000) who have shown that $\operatorname{Slr} 0513$ is indeed present in the soluble protein fraction of the periplasm in Synecho- cystis PCC 6803. On the other hand, the localization of Slr1295 (FutA1) has remained uncertain, since it was not among the group of periplasm-located soluble proteins identified by this group. To obtain more information about Slr1295, we investigated the localization of Slr1295 together with the localization of Slr0513 and have performed a detailed study of Synechocystis PCC 6803 WT and an Slr1295-free mutant grown under ironsufficient and iron-deficient conditions.

\section{METHODS}

Cyanobacterial strains and growth conditions. Synechocystis sp. strain PCC 6803 (subsequently called Synechocystis PCC 6803) was obtained from the Institut Pasteur, Collection Nationale de Cultures de Microorganismes, Paris, France, and was grown as described previously (Stephan et al., 2000). The bottles were illuminated with four Philips lamps (Cool Spot, $\left.\Varangle 12^{\circ}, 150 \mathrm{~W}\right)$ resulting in $161 \mu \mathrm{E} \mathrm{m}^{-2} \mathrm{~s}^{-1}$. Growth of the Slr1295-free Synechocystis PCC 6803 mutant was as above, except that the growth medium contained chloramphenicol $\left(8 \mathrm{mg} \mathrm{l}^{-1}\right)$.

For growth of Synechocystis under iron limitation, BG11 medium without $\mathrm{Fe}(\mathrm{III})$ citrate was used. Prior to transfer of cells into iron-free medium, cultures were grown for several cycles of 2 days under regular conditions, then harvested by centrifugation and once washed with $20 \mathrm{mM}$ sodium phosphate buffer, pH 7·0. In general, Synechocystis PCC 6803 [inoculation, $0 \cdot 4 \mu \mathrm{l}$ packed cell volume $(\mathrm{PCV}) \mathrm{ml}^{-1}$ ] was grown for $48 \mathrm{~h}$ under the given conditions. Growth was determined by measuring the $\mathrm{OD}_{750}$ of Synechocystis PCC 6803 cultures $\left[\mathrm{OD}_{750}\right.$ of $0 \cdot 1$ (up to a total absorbance of $<1$ ) corresponds to about $0 \cdot 1 \mu \mathrm{l} \mathrm{PCV} \mathrm{ml}{ }^{-1}$ ] (see also Flores et al., 1982).

Preparation of cell suspensions and cell-free extracts. For preparation of cell suspensions, Synechocystis cells were harvested by centrifugation for $30 \mathrm{~min}$ at $2200 \mathrm{~g}$ and then resuspended in MCMG buffer (20 mM MES/NaOH, pH 6.35, $5 \mathrm{mM} \mathrm{CaCl}_{2}, 5 \mathrm{mM} \mathrm{MgCl}_{2}, 25 \%$ glycerol) to give a cell density of $100 \mu \mathrm{l} \mathrm{PCV} \mathrm{ml} \mathrm{m}^{-1}$.

When cell-free extracts of Synechocystis were used, the above cell suspension $\left(100 \mu \mathrm{l} \mathrm{PCV} \mathrm{ml} \mathrm{m}^{-1}\right)$ was mixed with an equal volume of glass beads $(0 \cdot 17-0 \cdot 18 \mathrm{~mm})$ and treated in a 'Bead Beater' (Biospec Products; chamber vol. $15 \mathrm{ml}$ ) 10 to 15 times for $25 \mathrm{~s}$ with cooling intervals of $4 \mathrm{~min}$. After this treatment the cell extract was decanted from the beads and the beads were washed once with an equal volume of MCMG buffer. Subsequently, the two supernatants were combined. Thus, the obtained cell extract corresponded to a cell suspension of $50 \mu \mathrm{l}$ PCV ml ${ }^{-1}$. The cell extract was centrifuged for $10 \mathrm{~min}$ at $2000 \mathrm{~g}$ to remove the residual glass beads and unbroken cells.

Determination of photosynthetic activities. Photosynthetic $\mathrm{O}_{2}$ evolution/uptake with intact cells or cell-free extracts of Synechocystis PCC 6803 was measured in a Clark-type electrode (Rank Brothers) at a polarization voltage of $600 \mathrm{mV}$. The reaction temperature was $30^{\circ} \mathrm{C}$ for cell suspensions and $20{ }^{\circ} \mathrm{C}$ for cell-free extracts. Continuous red light was provided by a halogen lamp (24 V, $250 \mathrm{~W}$; Spindler and Hoyer). The light was filtered through a glass cuvette containing $2 \%(\mathrm{w} / \mathrm{v})$ $\mathrm{CuSO}_{4}$ and a red plexiglass filter (RG1-610; Schott). Light intensity on the water surface corresponded to $1995 \mu \mathrm{E} \mathrm{m} \mathrm{m}^{-2} \mathrm{~s}^{-1}$ $(400-740 \mathrm{~nm})$

$\mathrm{O}_{2}$ evolution of whole cells was determined in a reaction mixture of $3 \mathrm{ml}$ containing $54 \mathrm{mM}$ HEPES/ $\mathrm{NaOH}$, pH 7 0 , $15 \mathrm{mM} \mathrm{NaHCO}$ in BG11 medium and cell suspension 
corresponding to 5-20 $\mu \mathrm{g}$ chlorophyll (Chl). Alternatively, a reaction mixture containing $54 \mathrm{mM}$ HEPES/ $\mathrm{NaOH}, \mathrm{pH} 7 \cdot 0$, $1 \mathrm{mM}$ phenyl-p-benzoquinone (PBQ), $50 \mathrm{mM} \mathrm{CaCl}_{2}$ and cell suspension was used.

PS I activity was determined with cell-free extracts. The reaction mixture contained in a total volume of $3 \mathrm{ml}: 54 \mathrm{mM}$ HEPES/ $\mathrm{NaOH}, \mathrm{pH} 7 \cdot 0,0 \cdot 08 \mathrm{mM}$ 2,6-dichlorophenol-indophenol (DCPIP), 3.33 mM sodium ascorbate, $0.17 \mathrm{mM}$ methylviologen (MV), 0.4 mM KCN, 0.01 mM 3-(3,4-dichlorophenyl)-1,1-dimethylurea and cell-free extract corresponding to $5-20 \mu \mathrm{g}$ Chl.

PS II activity was determined in a reaction mixture of $3 \mathrm{ml}$ containing $54 \mathrm{mM}$ HEPES/NaOH, pH 7.0, $50 \mathrm{mM} \mathrm{CaCl}$, $400 \mathrm{mM}$ sucrose, $1.7 \mathrm{mM}$ potassium ferricyanide and cell-free extract corresponding to $10-20 \mu \mathrm{g} \mathrm{Chl}$.

Since iron-deficient growth leads to Chl reduction, photosynthetic activity values are always given on Chl basis (per mg Chl) and in addition on the basis of PCV (per $100 \mu \mathrm{l} \mathrm{PCV).}$ PCV was calculated from the $\mathrm{OD}_{750}$ (see above).

Pigment content, protein content, SDS-PAGE and immunoblotting. Chl content was estimated according to Grimme \& Boardman (1972), and phycocyanin and allophycocyanin content according to Tandeau de Marsac \& Houmard (1988). Protein content was determined either according to Smith et al. (1985) or Bradford (1976).

SDS-PAGE and immunoblotting were done as described previously (Exss-Sonne et al., 2000). Samples were denatured at $60^{\circ} \mathrm{C}$ for $30 \mathrm{~min}$. The antisera used were as follows: antiIdiA (IdiA from Synechococcus PCC 6301; Michel \& Pistorius, 1992), anti-Slr0513 (Slr0513 was isolated from the soluble protein fraction of the periplasm from Synechocystis PCC 6803; a kind gift of Dr Sabine Fulda), anti-PsbA, anti-PsbB, anti-PsbO and anti-AtpA (proteins from oat or tobacco; ExssSonne et al., 2000), anti-PsaA/B (PsaA/B from Synechocystis PCC 6803) and anti-C-phycocyanin (from Aphanotheca halophytica; Sigma) and anti-allophycocyanin (from Anabaena variabilis; Boehringer).

$77 \mathrm{~K} \mathrm{Chl} \mathrm{a} \mathrm{fluorescence} \mathrm{measurements.} 77 \mathrm{~K} \mathrm{Chl} \mathrm{a} \mathrm{fluor-}$ escence measurements were performed with a Perkin Elmer luminescence spectrometer LS50B. Excitation was at $435 \mathrm{~nm}$ and fluorescence emission was recorded between 650 and $800 \mathrm{~nm}$. Cells suspensions cultivated under iron-sufficient or iron-deficient conditions were adjusted to equal Chl concentration by dilution with BG11 medium ( \pm iron) to give a $\mathrm{Chl}$ concentration within the range of $2-10 \mu \mathrm{g} \mathrm{Chl} \mathrm{ml}{ }^{-1}$. Cells were immediately frozen in liquid nitrogen without any further pretreatment.

Isolation of Synechocystis PCC 6803 subcellular fractions. Preparation of the soluble protein fraction from periplasm and of the spheroplast fraction was done according to Block \& Grossman (1988). The soluble protein fraction of the periplasm was concentrated (about eightfold) by dialysis against $20 \%$ carbowax (PEG 20000). The pellet containing the spheroplasts was resuspended in $5 \mathrm{mM}$ Tris $/ \mathrm{HCl}, \mathrm{pH} 7 \cdot 5$, and broken by French pressure cell treatment at $138 \mathrm{MPa}$ and $4{ }^{\circ} \mathrm{C}$. Centrifugation for $1 \mathrm{~h}$ at $100000 \mathrm{~g}$ resulted in a soluble protein fraction and a pellet, which contained cytoplasmic and thylakoid membranes and which was resuspended in $5 \mathrm{mM}$ Tris/HCl, pH 7.5.

The cytoplasmic and thylakoid membranes were isolated with slight modifications according to the procedure described by Omata \& Murata (1984). Synechocystis WT cells (2.5 l cell suspension) were harvested by centrifugation, resuspended in $5 \mathrm{mM}$ HEPES/ $\mathrm{NaOH}$, pH 7.0, containing $600 \mathrm{mM}$ sucrose and $2 \mathrm{mM} \mathrm{Na}{ }_{2} \mathrm{EDTA}$, treated with lysozyme for $2 \mathrm{~h}$ at $28{ }^{\circ} \mathrm{C}$ and broken by passage through a prechilled French pressure cell at $40 \mathrm{MPa}$. The homogenate was centrifuged at $5000 \mathrm{~g}$ for $10 \mathrm{~min}$ to remove unbroken cells. The supernatant was subjected to density-gradient centrifugation as described by Omata \& Murata (1984).

Isolation of PS I complexes from Synechocystis PCC 6803 was done as described by Wenk \& Kruip (2000), and isolation of PS II complexes was done as described by Burnap et al. (1989) with slight modifications. The chromatography of the detergent-solubilized PS II complexes was done on a MonoQ column (Pharmacia) instead of a Toyopearl DEAE-M column and the $\mathrm{NaCl}$ gradient was extended to $500 \mathrm{mM} \mathrm{NaCl}$ instead of $200 \mathrm{mM} \mathrm{NaCl}$.

Ultrastructural and immunocytochemical investigations. Synechocystis PCC 6803 cells were grown and harvested as described above. A cell pellet obtained from $10 \mathrm{ml}$ cell suspension was washed three times with EM buffer $(50 \mathrm{mM}$ $\mathrm{KH}_{2} \mathrm{PO}_{4} / \mathrm{Na}_{2} \mathrm{HPO}_{4}, \mathrm{pH} 7 \cdot 0$ ). The ultrastructural and immunocytochemical investigations were performed as described previously (Engels et al., 1997).

Construction of the SIr1295-free Synechocystis PCC 6803 mutant. For construction of the Slr1295-free Synechocystis PCC 6803 mutant the primers P-5'-AACCTCCAGTTCCACTGACC- $3^{\prime}$ and P-5'-AGTCTGCCAACTGGTGACAA-3' were used to amplify a 1907 bp DNA fragment carrying the gene slr1295. The PCR-amplified fragment was cloned into SmaI-digested pK18mob (Schäfer et al., 1994). The insertion of a $\mathrm{Cm}^{\mathrm{R}}$ cassette with flanking $\Omega$ terminators preventing transcriptional read-through activites, taken from plasmid

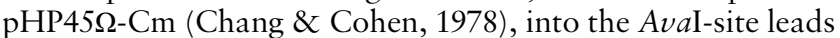
to insertional inactivation of the slr 1295 gene, leaving nearly equal flanking DNA regions on both sides of the fragment. Transformation of Synechocystis PCC 6803 with this 6987 bp construct (pK18mob1295 $\mathrm{Cm}^{\mathrm{R}}$ ) was performed according to Laudenbach \& Straus (1988).

Southern blotting. Southern blotting was performed as described in Sambrook et al. (1989). Genomic DNA from Synechocystis PCC 6803 WT and the Slr1295-free mutant was isolated by the Sarkosyl method, purified by the phenol extraction procedure (Williams, 1988) and then digested with SspI and ScaI or XmnI, or Alw NI and KpnI. The digested DNA was separated in a $1 \%$ agarose gel and transferred via capillary blotting onto a positively charged nylon membrane (Hybond-N ${ }^{+}$; Amersham). For hybridization a digoxigenin (Dig)-labelled pK18mob1295 $\mathrm{Cm}^{\mathrm{R}}$ probe was used, according to the manufacturer's recommendation.

Northern blotting. Northern blotting was done as previously described (Michel et al., 1999). The primers used to amplify the probes were $5^{\prime}$-AACCTCCAGTTCCACTGACC-3' and 5'-AGTCTGCCAACTGGTGACAA-3' for $s \operatorname{lr} 1295,5^{\prime}$-GGCAAGGATGGACAGCAGTA-3' and 5'-GCATTACTGCCAGCCAACTT-3' for slr0513, and 5'-GGTGGACAGAGACGCTTTATT-3' and 5'-TGGCTAATGACTAGGTTTGCA-3' for isiA.

\section{RESULTS AND DISCUSSION}

\section{Construction of an SIr1295-free Synechocystis PCC 6803 mutant}

Plasmid pK18mob1295 $\mathrm{Cm}^{\mathrm{R}}$ (see Methods) was used for insertional inactivation of slr1295 in Synechocystis PCC 6803. The $\mathrm{Cm}^{\mathrm{R}}$ gene in the plasmid has the same orientation as the slr1295 gene. The mutant was verified by Southern blot analysis of the corresponding $\mathrm{Cm}^{\mathrm{R}}$ and 


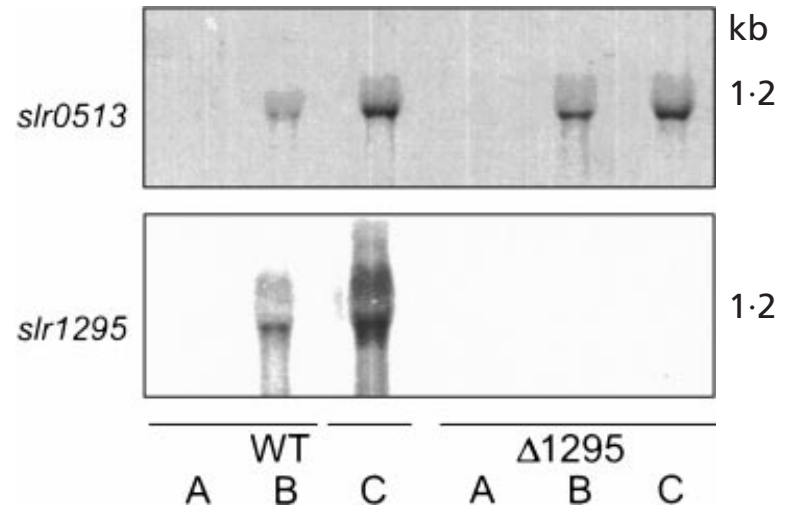

Fig. 1. Northern blot analysis of s/r1295 and s/r0513 mRNA expression. Synechocystis PCC 6803 WT and the SIr1295-free mutant were grown for 2 days in iron-sufficient medium (A) and for 2 (B) or 4 days (C) in iron-deficient medium. Detection of s/r1295 and s/r0513 mRNA was achieved by DNA/RNA hybridization using the corresponding Dig-labelled probe.

$\mathrm{Km}^{\mathrm{S}}$ clones. As shown below, the mutant did not contain any detectable slr1295 mRNA, nor the Slr1295 protein (see Figs 1 and 2). This Slr1295-free Synechocystis PCC 6803 mutant $(\Delta 1295)$ was used in subsequent experiments.

\section{Analysis of the expression of SIr1295 and SIr0513 at the mRNA and protein level}

Expression of Slr1295 and Slr0513 was analysed in Synechocystis PCC 6803 cells grown under ironsufficient and iron-deficient conditions. For these experiments, cells were cultivated for 2 days under ironsufficient conditions $(+\mathrm{Fe}: 2 \mathrm{~d})$ and for 2 days $(-\mathrm{Fe}: 2 \mathrm{~d})$ or 4 days $(-\mathrm{Fe}: 4 \mathrm{~d})$ under iron-deficient conditions (medium without $\mathrm{Fe}^{3+}$ citrate). In the experiments with cells grown for 4 days under iron deficiency $(-\mathrm{Fe}: 4 \mathrm{~d})$, the cells were grown for 2 days under iron deficiency and then diluted into fresh iron-deficient medium and grown for another 2 days. The results of the Northern blot analysis are given in Fig. 1. Under the chosen conditions, only a low level of mRNA for slr1295 and slr0513 was present in WT cells grown under iron-sufficient conditions. The transcript level substantially increased under iron limitation. This increase was already seen in 2-day iron-depleted cells. As expected, the Slr1295-free mutant did not contain any detectable slr1295 mRNA, confirming that the mutant was fully segregated. In the Slr1295-free mutant, as well as in the WT, the slr0513 mRNA level was low under iron-sufficient conditions and increased under iron-deficient conditions.

Expression of Slr1295 and Slr0513 at the protein level was analysed with an anti-IdiA antiserum raised against IdiA isolated from Synechococcus PCC 6301 (Michel \& Pistorius, 1992), and with an antiserum raised against the Slr0513 protein which was isolated from the soluble protein fraction of the periplasm from Synechocystis PCC 6803. The results of the immunoblot analysis are given in Fig. 2. Two very weak protein bands were detectable after immunostaining with the anti-IdiA antiserum in WT cells cultivated under iron-sufficient conditions. The expression of both proteins was highly increased under iron limitation. As expected, in the Slr1295-free mutant only one protein with an increased expression under iron limitation was detected, corresponding to the lower band in WT cells. Thus, the upper band in WT cells represents Slr1295, which is missing in the mutant, and the lower band represents Slr0513, which is present in the mutant. The results in Fig. 2 also show that the anti-Slr0513 antiserum only recognizes the lower band in WT cells and thus only cross-reacts with Slr0513, the protein against which the antiserum was raised. This antiserum is slightly more sensitive in detecting small amounts of Slr0513 than anti-IdiA antiserum. Thus, a $10 \%$ SDS-polyacrylamide gel (Tris-glycine buffer system) can resolve the two proteins under investigation: Slr1295 migrates slightly slower (upper band, apparent molecular mass $35 \mathrm{kDa}$ )

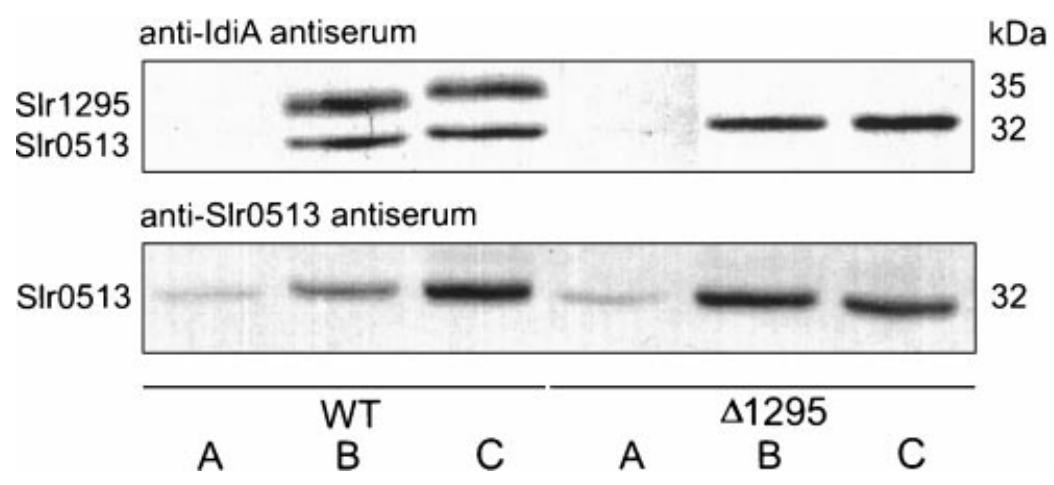

Fig. 2. Immunoblot analysis of SIr1295 and SIr0513 protein expression. Synechocystis PCC 6803 WT and SIr1295-free mutant cells were grown for 2 days in iron-sufficient medium (A) and for 2 (B) or 4 days (C) in iron-deficient medium. Detection of the SIr1295 and Slr0513 proteins was achieved with the anti-IdiA antiserum (dilution 1:500), which recognizes both proteins, and the anti-SIr0513 antiserum (dilution 1:1000) which only cross-reacts with Slr0513, but is slightly more sensitive. Total cell-free extracts corresponding to $25 \mu \mathrm{g}$ protein were applied in each lane. 
Table 1. Growth and pigment content of Synechocystis PCC 6803 WT and the SIr1295-free mutant

After growth for 2 days under iron-sufficient conditions ( $+\mathrm{Fe}: 2 \mathrm{~d})$ or for 2 days $(-\mathrm{Fe}: 2 \mathrm{~d})$ or 4 days $(-\mathrm{Fe}$ : $4 \mathrm{~d})$ under iron-deficient conditions, cells were harvested and resuspended to give a cell density of $100 \mu \mathrm{l} \mathrm{PCV} \mathrm{ml}{ }^{-1}$. Chl was determined in the cell suspensions; phycocyanin and allophycocyanin were determined in broken cell extracts. Details are given in Methods.

\begin{tabular}{|c|c|c|c|c|c|}
\hline $\begin{array}{l}\text { Synechocystis } \\
\text { PCC } 6803\end{array}$ & $\begin{array}{l}\text { Growth } \\
\text { conditions }\end{array}$ & Growth $\left(\mathrm{OD}_{750}\right)$ & $\begin{array}{l}\text { Chl (mg per } 100 \mu l \\
\text { PCV) }\end{array}$ & \multicolumn{2}{|c|}{$\begin{array}{l}\text { Phycocyanin/allophycocyanin } \\
\quad(\text { mg per } 100 \mu \mathrm{l} \text { PCV) }\end{array}$} \\
\hline \multirow[t]{3}{*}{ WT } & $+\mathrm{Fe}: 2 \mathrm{~d}$ & $0 \cdot 4 \rightarrow 3 \cdot 1 \pm 0 \cdot 3$ & $0 \cdot 560 \pm 0 \cdot 11$ & $2 \cdot 89 \pm 0.51$ & $1 \cdot 10 \pm 0 \cdot 33$ \\
\hline & $-\mathrm{Fe}: 2 \mathrm{~d}$ & $0.4 \rightarrow 2.9 \pm 0.5$ & $0 \cdot 432 \pm 0 \cdot 03$ & $2.91 \pm 0.54$ & $1 \cdot 08 \pm 0 \cdot 32$ \\
\hline & $-\mathrm{Fe}: 4 \mathrm{~d}^{*}$ & $0 \cdot 4 \rightarrow 1 \cdot 7 \pm 0 \cdot 6$ & $0 \cdot 323 \pm 0 \cdot 02$ & $0 \cdot 96 \pm 0 \cdot 10$ & $0 \cdot 37 \pm 0.04$ \\
\hline \multirow[t]{3}{*}{ Mutant $\Delta 1295$} & $+\mathrm{Fe}: 2 \mathrm{~d}$ & $0 \cdot 4 \rightarrow 2 \cdot 9 \pm 0 \cdot 3$ & $0.577 \pm 0.09$ & $2.57 \pm 0.43$ & $1 \cdot 16 \pm 0 \cdot 47$ \\
\hline & $-\mathrm{Fe}: 2 \mathrm{~d}$ & $0 \cdot 4 \rightarrow 2 \cdot 5 \pm 0 \cdot 3$ & $0 \cdot 295 \pm 0 \cdot 08$ & $1 \cdot 85 \pm 0.45$ & $0 \cdot 70 \pm 0 \cdot 25$ \\
\hline & $-\mathrm{Fe}: 4 \mathrm{~d}^{*}$ & $0 \cdot 4 \rightarrow 1 \cdot 1 \pm 0 \cdot 4$ & $0 \cdot 165 \pm 0 \cdot 01$ & $0 \cdot 52 \pm 0 \cdot 10$ & $0 \cdot 21 \pm 0 \cdot 03$ \\
\hline
\end{tabular}

*In the experiments with cells grown for 4 days under iron deficiency ( $-\mathrm{Fe}: 4 \mathrm{~d}$ ), the cells were grown for 2 days under iron deficiency and then diluted into fresh iron-deficient medium and were grown for another 2 days. The values of the second cycle are given.

Table 2. Photosynthetic activities of Synechocystis PCC 6803 WT and the SIr1295-free mutant

Cells were cultivated as described in the legend to Table 1 . The activity measurements were performed with cell suspensions $\left(\mathrm{H}_{2} \mathrm{O} \rightarrow \mathrm{NaHCO}_{3}\right)$ or with broken extracts (PS II and PS I activity) as described in Methods. Data from two representative experiments are given.

\begin{tabular}{|c|c|c|c|c|c|c|c|}
\hline \multirow{3}{*}{$\begin{array}{l}\text { Synechocystis } \\
\text { PCC } 6803\end{array}$} & \multirow{3}{*}{$\begin{array}{c}\text { Growth } \\
\text { conditions }\end{array}$} & \multicolumn{2}{|c|}{$\mathrm{H}_{2} \mathrm{O} \rightarrow \mathrm{NaHCO}_{3}$} & \multicolumn{2}{|c|}{$\mathrm{H}_{2} \mathrm{O} \rightarrow \mathrm{K}_{3}\left[\mathrm{Fe}(\mathrm{CN})_{6}\right]$} & \multicolumn{2}{|c|}{ DCPIP/Asc. $\rightarrow \mathrm{MV}$} \\
\hline & & \multicolumn{6}{|c|}{$\mu \mathrm{mol} \mathrm{O}_{2}$ evolved or taken up $\mathrm{h}^{-1}$ per: } \\
\hline & & $100 \mu 1 \mathrm{PCV}$ & mg Chl & $100 \mu 1 \mathrm{PCV}$ & mg Chl & $100 \mu 1 \mathrm{PCV}$ & mg Chl \\
\hline \multirow[t]{6}{*}{ WT } & $+\mathrm{Fe}: 2 \mathrm{~d}$ & $135 \cdot 7$ & $201 \cdot 7$ & $137 \cdot 0$ & $203 \cdot 6$ & $125 \cdot 3$ & $186 \cdot 2$ \\
\hline & & $94 \cdot 1$ & $180 \cdot 9$ & $149 \cdot 8$ & $287 \cdot 9$ & $99 \cdot 1$ & $190 \cdot 5$ \\
\hline & $-\mathrm{Fe}: 2 \mathrm{~d}$ & $71 \cdot 0$ & $167 \cdot 7$ & $76 \cdot 3$ & $180 \cdot 4$ & $54 \cdot 6$ & $182 \cdot 9$ \\
\hline & & $116 \cdot 6$ & $286 \cdot 9$ & $69 \cdot 2$ & $170 \cdot 4$ & $70 \cdot 5$ & $173 \cdot 5$ \\
\hline & $-\mathrm{Fe}: 4 \mathrm{~d} *$ & $32 \cdot 8$ & $110 \cdot 0$ & $42 \cdot 1$ & $140 \cdot 9$ & $44 \cdot 8$ & $150 \cdot 1$ \\
\hline & & $33 \cdot 0$ & $97 \cdot 3$ & $56 \cdot 8$ & $167 \cdot 8$ & $31 \cdot 6$ & $93 \cdot 2$ \\
\hline \multirow[t]{6}{*}{ Mutant $\Delta 1295$} & $+\mathrm{Fe}: 2 \mathrm{~d}$ & $167 \cdot 1$ & $250 \cdot 5$ & $143 \cdot 6$ & $215 \cdot 3$ & $127 \cdot 5$ & $191 \cdot 1$ \\
\hline & & $106 \cdot 0$ & $197 \cdot 4$ & $101 \cdot 3$ & $188 \cdot 6$ & $107 \cdot 7$ & $200 \cdot 4$ \\
\hline & $-\mathrm{Fe}: 2 \mathrm{~d}$ & $65 \cdot 5$ & $170 \cdot 4$ & $69 \cdot 5$ & $180 \cdot 9$ & $22 \cdot 5$ & $142 \cdot 1$ \\
\hline & & $65 \cdot 3$ & $270 \cdot 9$ & $36 \cdot 8$ & $152 \cdot 8$ & $41 \cdot 5$ & $172 \cdot 0$ \\
\hline & $-\mathrm{Fe}: 4 \mathrm{~d} *$ & $12 \cdot 7$ & $80 \cdot 4$ & $19 \cdot 6$ & $123 \cdot 6$ & $22 \cdot 9$ & $144 \cdot 4$ \\
\hline & & $2 \cdot 4$ & $13 \cdot 8$ & $27 \cdot 7$ & $156 \cdot 9$ & $25 \cdot 0$ & $141 \cdot 4$ \\
\hline
\end{tabular}

*In the experiments with cells grown for 4 days under iron deficiency ( $-\mathrm{Fe}: 4 \mathrm{~d}$ ), the cells were grown for 2 days under iron deficiency and then diluted into fresh iron-deficient medium and were grown for another 2 days. The values for the second cycle are given.

than Slr0513 (lower band, apparent molecular mass $32 \mathrm{kDa})$. Both proteins are detected by anti-IdiA antiserum, while the anti-Slr0513 antiserum only crossreacts with Slr0513.

\section{Comparative analysis of growth, pigment content and photosynthetic activities}

Growth, pigment content and photosynthetic activities of Synechocystis PCC 6803 WT and the Slr1295-free mutant were analysed under iron-sufficient and irondeficient growth conditions. The results (Table 1) show that growth measured as $\mathrm{OD}_{750}$ was reduced after 4 days of iron-deficient conditions $(-\mathrm{Fe}: 4 \mathrm{~d}$ ) from $3 \cdot 1$ to $1 \cdot 7$ and from $2 \cdot 9$ to $1 \cdot 1$ for the WT and mutant, respectively, showing that the reduction was higher in the mutant than in the WT (45 vs $62 \%$ ). A higher decrease was also observed in pigment content. The reduction in Chl, phycocyanin and allophycocyanin content in the WT corresponded to 42,67 and $66 \%$, respectively; the corresponding values in the $\operatorname{Sir} 1295$-free mutant were 71,80 and $82 \%$, respectively.

The $\mathrm{O}_{2}$-evolving activity with bicarbonate was determined in intact cells, and partial activities were measured in cell-free extracts or intact cells. Since the Chl content per cell decreased under iron depletion, values shown in Table 2 (data for two representative 
Table 3. $\mathrm{O}_{2}$-evolving activity with PBQ as electron acceptor

Activity was determined in cell suspensions of Synechocystis PCC 6803 WT and the Slr1295-free mutant grown for 2 days under iron-sufficient conditions. Data for two representative experiments are given.

\begin{tabular}{|c|c|c|c|}
\hline \multirow{2}{*}{$\begin{array}{l}\text { Synechocystis } \\
\text { PCC } 6803\end{array}$} & \multirow[t]{2}{*}{ Chl $(\mathrm{mg}$ per $100 \mu \mathrm{l} \mathrm{PCV})$} & \multicolumn{2}{|c|}{$\mathrm{H}_{2} \mathrm{O} \rightarrow \mathrm{PBQ} \mu \mathrm{mol} \mathrm{O}_{2}$ evolved $\mathrm{h}^{-1}$ per: } \\
\hline & & $100 \mu 1 \mathrm{PCV}$ & mg Chl \\
\hline \multirow[t]{2}{*}{ WT } & $0 \cdot 48$ & $165 \cdot 6$ & $345 \cdot 5$ \\
\hline & $0 \cdot 42$ & $115 \cdot 5$ & $274 \cdot 2$ \\
\hline \multirow[t]{2}{*}{$\Delta 1295$} & 0.53 & $72 \cdot 4$ & $135 \cdot 6$ \\
\hline & $0 \cdot 40$ & $77 \cdot 1$ & $191 \cdot 4$ \\
\hline
\end{tabular}

experiments are shown in Table 2 and mean values are given in the text) were always calculated on the basis of $100 \mu \mathrm{l} \mathrm{PCV}$ and on the basis of Chl. On the PCV basis, the overall photosynthetic activity dropped after 4 days under iron depletion by $71 \%$ in the WT and by $94 \%$ in the mutant (the corresponding values on the Chl basis are 46 and $79 \%$ ). On the PCV basis, PS II as well as PS I activities were reduced by about $65 \%$ in the WT and by about $80 \%$ in the mutant. Measurements with intact cells and with PBQ as electron acceptor gave evidence that in mutant cells the PS II activity was already lower than in the WT when cells were grown under ironsufficient conditions (Table 3). A higher susceptibility of PS II for inactivation in the mutant was also obvious when cells were cultivated for $3 \mathrm{~h}$ in the presence of $30 \mathrm{mM} \mathrm{H}_{2} \mathrm{O}_{2}$. The PS II activity measured with PBQ as electron acceptor dropped by about 10 and $40 \%$ in the WT and mutant, respectively (not shown).

Immunoblot analysis of a selected number of thylakoid proteins (Fig. 3) gave evidence that the PsbA content decreased greatly under iron deficiency in Synechocystis PCC 6803 WT and the Slr1295-free mutant. However, in the mutant the amount of PsbA was less than in the WT even under iron-sufficient conditions. On the contrary, the amount of PsaA/B increased under iron deficiency in the WT as well as in the mutant, although the PS I activities were lower under iron deficiency. This inconsistency might be due to the observed modification of PS I under iron deficiency (see below).

\section{$77 \mathrm{~K} \mathrm{Chl} \mathrm{a} \mathrm{fluorescence} \mathrm{and} \mathrm{isolation} \mathrm{of} \mathrm{PS} \mathrm{I}$ complexes}

One major difference between Synechocystis PCC 6803 WT and Slr1295-free mutant cells grown under iron deficiency was the height of the $77 \mathrm{~K} \mathrm{Chl} a$ fluorescence peak at $685 \mathrm{~nm}$ (Fig. 4). As previously shown, the increase of $77 \mathrm{~K} \mathrm{Chl} a$ fluorescence at $685 \mathrm{~nm}$ is due to the expression of IsiA, a CP43 homologue, under iron limitation (Burnap et al., 1993; Falk et al., 1995; Park et al., 1999; and see reviews Ferreira \& Straus 1994; Straus 1994). Moreover, evidence was recently presented that IsiA forms a new PS I antenna under iron deficiency in Synechocystis PCC 6803 (Bibby et al., 2001a, b) as well

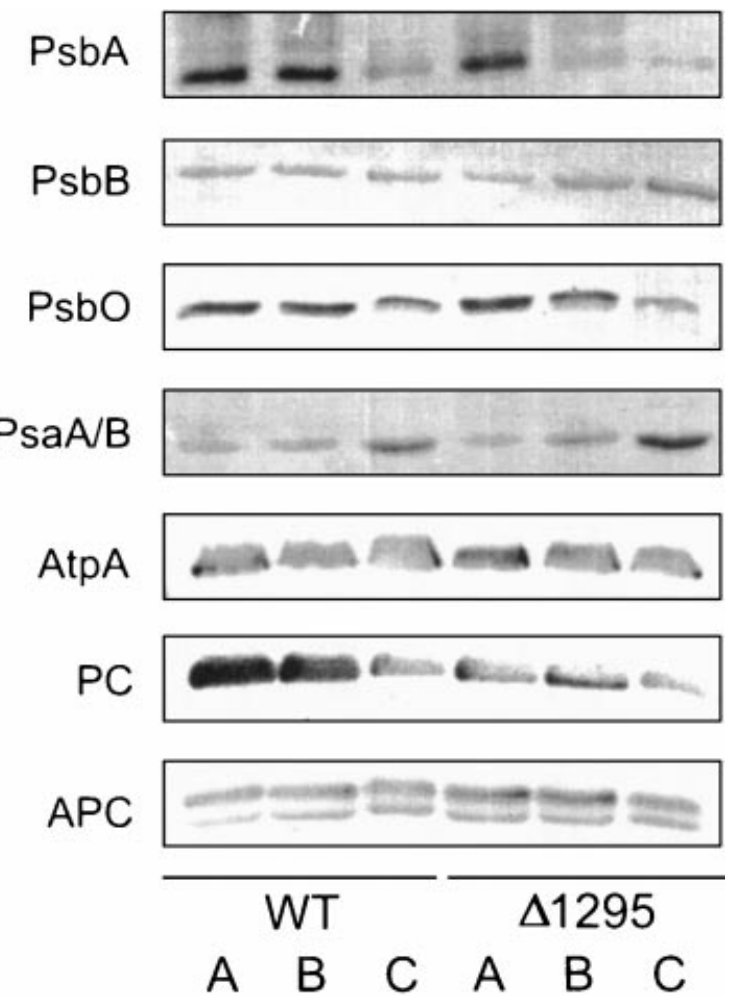

Fig. 3. Immunoblot analysis of some selected thylakoid membrane proteins. Synechocystis PCC 6803 WT and the SIr1295-free mutant were grown for 2 days in iron-sufficient medium (A) and for 2 (B) or 4 days (C) in iron-deficient medium. Detection was with antisera raised against PsbA (dilution 1:500), PsbB (1:50), PsbO (1:250), PsaA/B (1:1000), AtpA $(1: 1000)$, phycocyanin (PC, 1:1000) and allophycocyanin (APC, $1: 1000)$. Total cell-free extracts corresponding to $25 \mu \mathrm{g}$ protein (except for PsaA/B, $50 \mu$ g protein) were applied to each lane.

as in Synechococcus PCC 7942 (Boekema et al., 2001). As can be clearly seen in Fig. 4, the fluorescence emission peak at $685 \mathrm{~nm}$ was significantly higher in the mutant than in the WT when cells were grown for 2 days under iron deficiency.

Because of these differences PS I complexes were isolated 


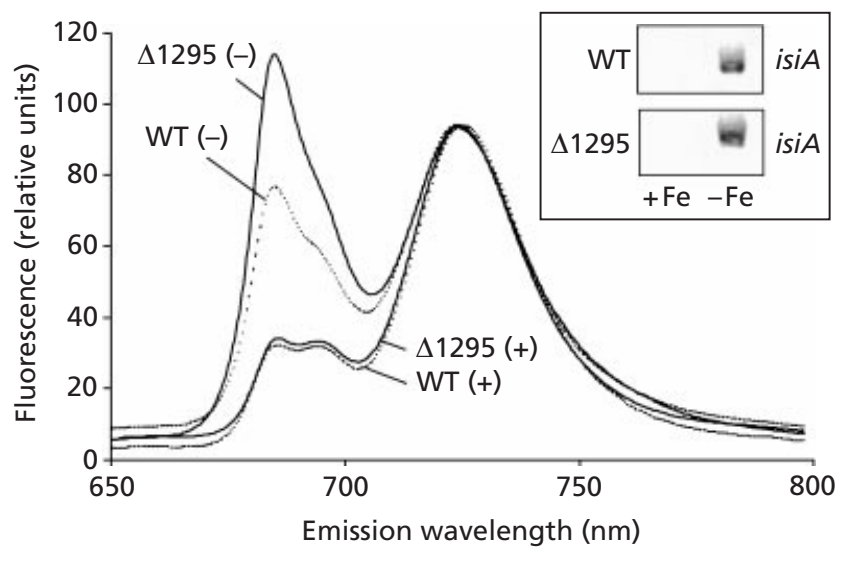

Fig. 4. $77 \mathrm{~K} \mathrm{Chl}$ a fluorescence of Synechocystis PCC 6803 WT and SIr1295-free mutant cells grown under iron-sufficient and iron-deficient conditions. Synechocystis PCC 6803 WT and the SIr1295-free mutant were grown for 2 days under ironsufficient conditions and for 2 days under iron-deficient conditions. Excitation was at $435 \mathrm{~nm}$, fluorescence emission was recorded between 650 and $800 \mathrm{~nm}$ and emission spectra were normalized to the PS I peak. Cells were adjusted to equal $\mathrm{Chl}$ values by dilution $\left(3 \mu \mathrm{g} \mathrm{Chl} \mathrm{ml}{ }^{-1}\right)$ and then immediately frozen in liquid nitrogen. The insert shows the expression of the isiA mRNA in WT and mutant cells cultivated for 2 days either under iron-sufficient $(+\mathrm{Fe})$ or iron-deficient $(-\mathrm{Fe})$ conditions.

from Synechocystis PCC 6803 WT and the Slr1295-free mutant grown under iron-sufficient and iron-deficient conditions (Fig. 5). As the elution profiles from an anion exchange column show, after growth for 2 days under iron deficiency in the WT as well as in the mutant the PS I-IsiA complex was formed, which is not present under iron-sufficient growth conditions. The major difference between the WT and the Slr1295-free mutant was the presence of a substantial amount of regular PS I trimers besides the PS I-IsiA complexes in the WT, while in the mutant only a minor amount of PS I trimers was present. This also indicates that in the Slr1295-free mutant iron limitation is more severe than in the WT, and therefore the modification of regular PS I trimers to PS I-IsiA supercomplexes is more advanced in the mutant than in the WT.

\section{Biochemical investigations about the localization of SIr1295 and SIr0513}

The localization of Slr1295 and Slr0513 was investigated by two different experimental approaches. The soluble protein fraction of the periplasm and the spheroplast fraction were isolated from Synechocystis PCC 6803, according to the procedure of Block \& Grossman (1988). Subsequently, the spheroplast fraction was further treated by passing it through a prechilled French press. The extract was separated by centrifugation into a soluble protein fraction and a membrane fraction containing cytoplasmic and thylakoid membranes. The presence of Slr1295 and Slr0513 in these cell fractions was analysed with the anti-IdiA antiserum which recognizes both proteins, and with the anti-Slr0513

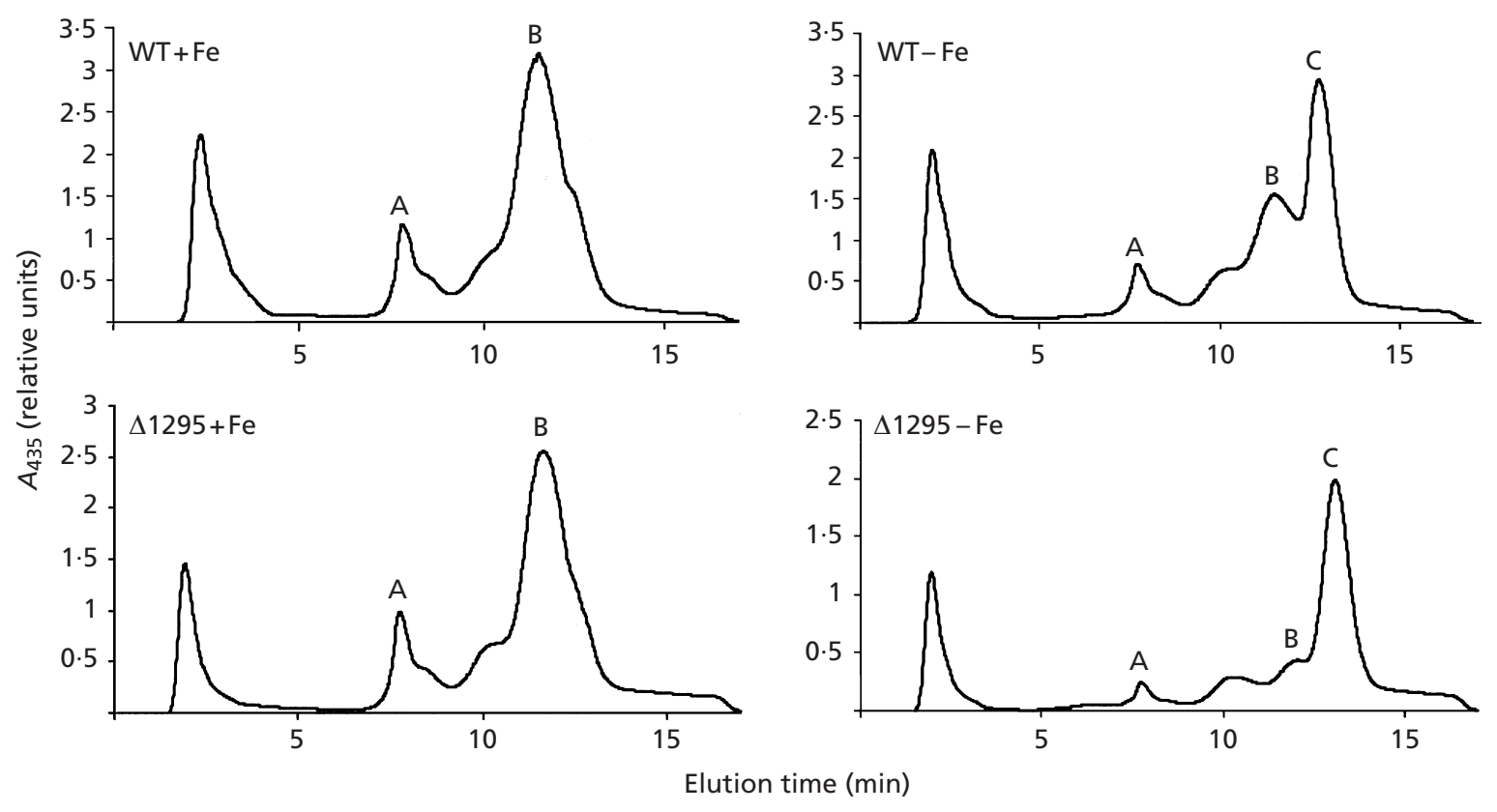

Fig. 5. Elution profiles of detergent solubilized PS I complexes from Synechocystis PCC 6803 WT and the SIr1295-free mutant. PS I complexes were solubilized from thylakoid membranes of Synechocystis PCC 6803 WT and the SIr1295-free mutant grown for 2 days under either iron-sufficient or iron-deficient conditions. The detergent-solubilized PS I complexes were submitted to an anion-exchange chromatography column (Poros $50 \mathrm{HQ}$ ) and the corresponding elution profiles are given. A, PS I monomers; B, PS I trimers; C, PS I-IsiA complexes. 


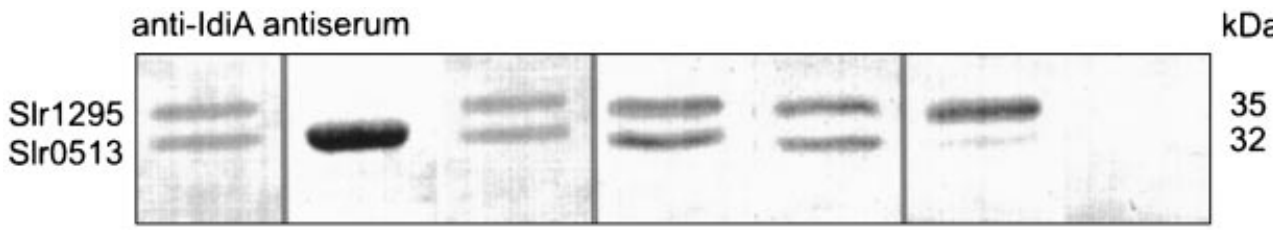

anti-SIr0513 antiserum

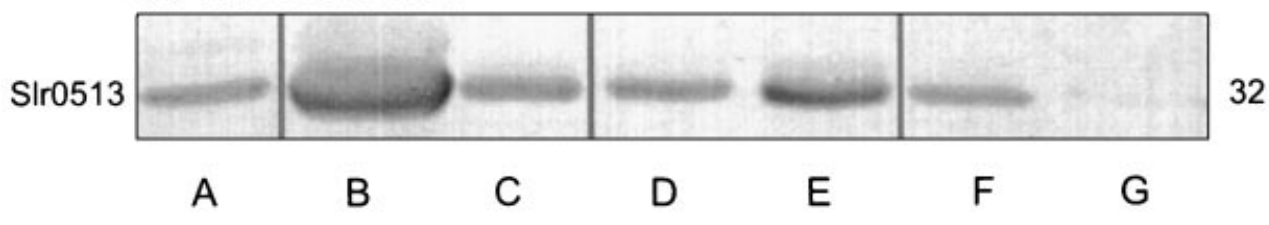

Fig. 6. Detection of SIr 1295 and SIr0513 in various subcellular fractions of Synechocystis PCC 6803 WT grown under irondeficient conditions. All subcellular fractions were obtained from Synechocystis PCC 6803 WT grown for 2 days under iron limitation. Immunoblot analysis was performed with the anti-IdiA antiserum (dilution 1:500) and the anti-SIr0513 antiserum (1:1000). A, Total cell-free extract; B, soluble protein fraction of the periplasm; C, total cell-free extract of spheroplast fraction after French press treatment; $D$, soluble protein fraction of spheroplast preparation; $E$, total membrane fraction of spheroplast preparation; F, thylakoid membranes; G, cytoplasmic membranes. Twenty-five micrograms protein (except for periplasm fraction, $15 \mu \mathrm{g}$ protein) was applied in each lane.
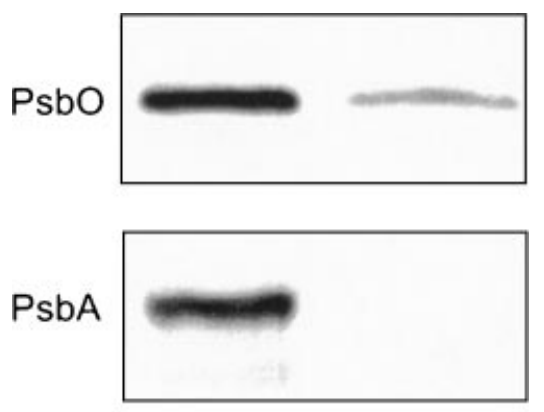

A

B

Fig. 7. Detection of PsbO in the soluble protein fraction of the periplasm. The subcellular fractions were obtained from Synechocystis PCC 6803 WT grown for 2 days under iron limitation. Immunoblot analysis was done with the anti-PsbO antiserum (dilution $1: 250)$ and the anti-PsbA antiserum $(1: 500)$ (as a control for an intrinsic PS II polypeptide). A, Total extract of spheroplast fraction after French press treatment; B, soluble protein fraction of the periplasm. Twenty micrograms protein was applied in each lane.

antiserum which recognizes only Slr0513. As can be seen in Fig. 6, Slr0513 is present in substantial amounts in the soluble protein fraction of the periplasm. The same is true for PsbO (Fig. 7), which was used as a reference protein. PsbO is associated with the donor side of PS II, but is also found in the periplasm (see e.g. Zak et al., 2001). Besides being present in the periplasm, Slr0513 was also found in the spheroplast fraction, being about equally distributed between the soluble and membrane protein fractions. In contrast, Slr1295 was not detectable in the periplasm fraction (although the periplasmic fraction was concentrated about eightfold). Slr1295 was only present in the spheroplast fraction where it was about equally distributed between soluble and membrane protein fractions.
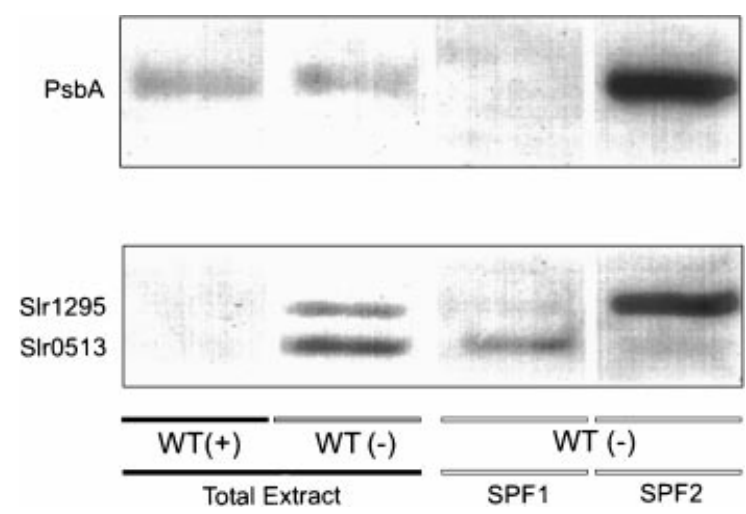

Fig. 8. Detection of SIr1295 in detergent-solubilized PS IIenriched fractions of thylakoid membranes from Synechocystis PCC 6803 WT grown for 2 days under iron limitation. PS II complexes of Synechocystis PCC 6803 WT grown for 2 days under iron limitation were isolated as described in Methods. Detection of SIr1295 and SIr0513 in immunoblots was achieved with the anti-IdiA antiserum (dilution 1:500). As a reference for PS II enrichment the detection of PsbA was used (detected by the anti-PsbA antiserum, 1:500). The applied samples were: WT $(+)$, total cell-free extract of WT grown under ironsufficient conditions; WT(-), total cell-free extract of WT grown under iron limitation; WT(-) solubilized protein fraction 1 (SPF1), containing proteins only loosely attached to the thylakoid membrane, as is the case for Slr0513; WT (-) solubilized protein fraction 2 (SPF 2), the PS II-enriched fraction containing SIr1295.

To answer the question, whether the membraneassociated part of Slr0513 and Slr1295 was attached to the cytoplasmic and/or thylakoid membrane, these membranes were isolated separately, according to the procedure described by Omata \& Murata (1984). As shown in Fig. 6, Slr1295 was not detectable in the cytoplasmic membrane fraction, while minor amounts 


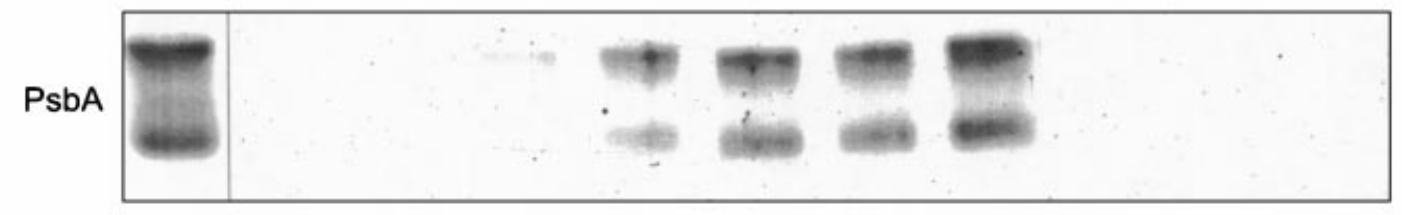

anti-IdiA antiserum

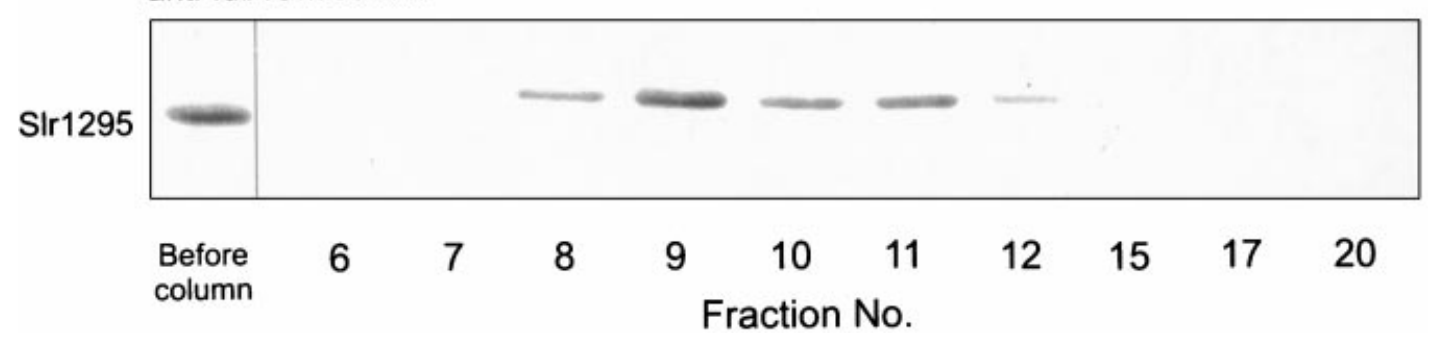

Fig. 9. Co-purification of SIr1295 with PS II complexes. The detergent-solubilized PS II complexes were submitted to chromatography on a MonoQ column. The fractions (8-12) containing PS II complexes (identified by the anti-PsbA antiserum, dilution 1:500) also contain SIr1295 (identified by the anti-IdiA antiserum, 1:500).

of Slr0513 were found (lane G). In the thylakoid membrane fraction a substantial amount of Slr1295 was detected, while in contrast only minor amounts of Slr0513 were present (lane F).

Since a substantial amount of Slr1295 was associated with the thylakoid membranes, the question was asked how tightly this protein is associated and whether it interacts preferentially with PS I or PS II. Neither Slr1295 nor Slr0513 was detectable in isolated PS I complexes (not shown). For PS II isolation, the membrane fraction obtained after breaking the cells was washed first with a low concentration of dodecyl maltoside to remove phycobili proteins and only loosely associated proteins. In the wash supernatant a small amount of Slr0513 but no Slr1295 was detectable, implying that Slr1295 was relatively tightly associated with the thylakoid membranes, while Slr0513 was only loosely bound (Fig. 8, SPF 1). Subsequently, PS II complexes were solubilized with a combination of dodecyl maltoside and octyl glucopyranoside. In the PS II-containing fraction an enrichment of Slr1295 was clearly seen in parallel to the enrichment of the PsbA protein (Fig. 8, SPF 2). The PS II complexes were further purified on an FPLC-MonoQ column. Subsequent immunoblot analysis gave evidence that the Slr1295 protein co-purified with the reaction centre of PS II (Fig. 9). Only a very slight shift of Slr1295 relative to the D1 polypeptide was seen, most likely due to different subpopulations of PS II.

\section{Immunocytochemical detection of SIr1295 and SIr0513}

For immunocytochemical investigations Synechocystis PCC 6803 WT and Slr1295-free mutant cells were grown under iron-sufficient or iron-deficient conditions for
2 days. Subsequently, the cells were prepared as previously described (Engels et al., 1997) and then treated with anti-IdiA (Fig. 10) or anti-Slr0513 (Fig. 11) antiserum followed by gold-conjugated anti-rabbit IgG. When electron micrographs of WT cells grown under iron-sufficient conditions were compared to those cells cultivated for 2 days under iron-deficient conditions, it became apparent that there was a substantial increase in gold labels (compare panels a and b in Figs 10 and 11). The same was true for the Slr1295-free mutant (not shown). However, unexpectedly, the majority of labels for Slr1295 as well as Slr0513 was found intracellularly - mainly associated with the thylakoid membrane. Only some minor labels were present in the periplasm.

The results shown here on the localization of Slr1295 give evidence that Slr1295 mainly has an intracellular function, since virtually no Slr1295 was detected in the soluble protein fraction of the periplasm or in the cytoplasmic membrane of WT cells when grown under mild iron limitation. These results are consistent with the immunocytochemical localization showing that the majority of the gold labels was found intracellularly. The same was true for Slr0513. Only minor labels were present in the periplasm. However, in the case of Slr0513, in contrast to Slr1295, the biochemical investigations showed that substantial amounts of Slr0513 were present in the soluble protein fraction of the periplasm, a result in agreement with the results of Fulda et al. (2000). A possible explanation of this discrepancy could be that thylakoid membranes in part are connected with the cytoplasmic membrane (Nierzwicki-Bauer et al., 1983; see also Zak et al., 2001). Therefore, it might be possible that some of the Slr0513 which was found in the soluble protein fraction of the periplasm originated from the intrathylakoid space (lumen). This might also explain the presence of PsbO in this fraction. Thus for 

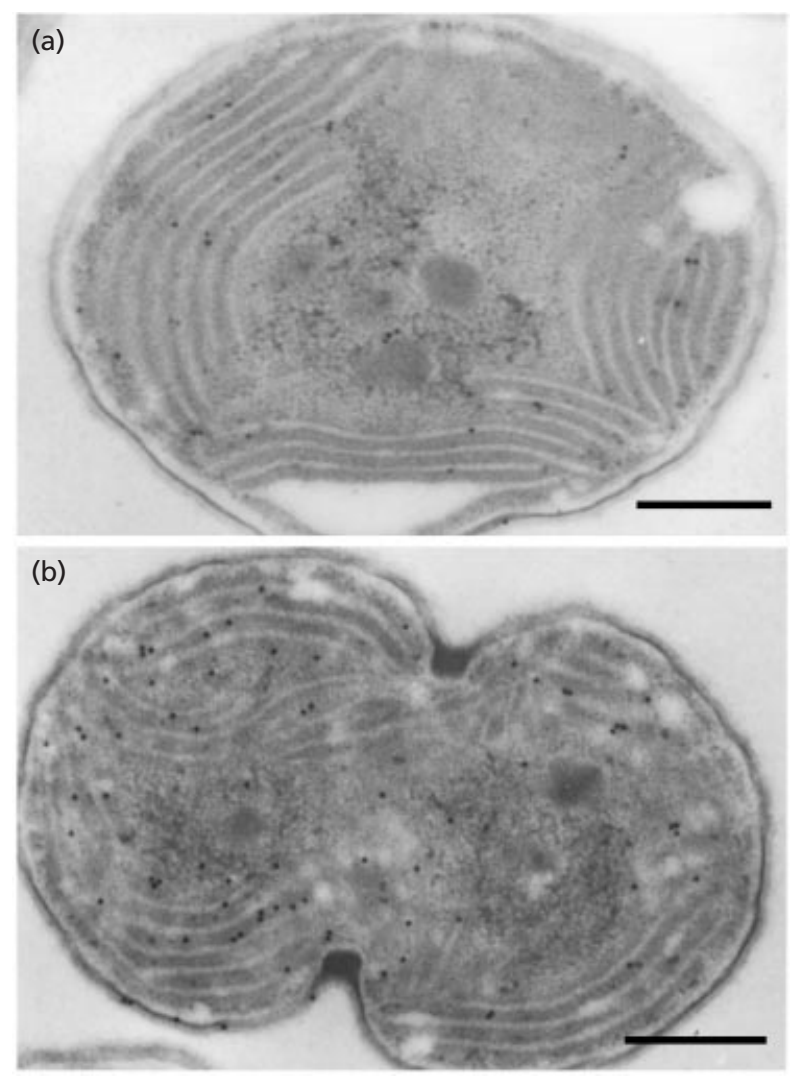

Fig. 10. Electron micrographs of Synechocystis PCC 6803 WT cells grown under iron-sufficient and iron-deficient conditions: immunocytochemical detection of SIr1295 and SIr0513 by the anti-IdiA antiserum. (a) Synechocystis PCC 6803 cells were cultivated for 2 days under iron-sufficient conditions and treated with the anti-IdiA antiserum (dilution 1:100) in combination with gold-labelled anti-rabbit IgG (1:30). (b) Cells were grown for 2 days under iron-deficient conditions and treated as described for (a). Bars, $0.5 \mu \mathrm{m}$. Electron micrographs of cells grown for 2 days under iron-deficient conditions and treated with the corresponding pre-immune serum $(1: 100)$ in combination with gold-labelled anti-rabbit IgG showed hardly any gold labelling (not shown).

Slr0513, transport into the periplasm and the lumen is indicated.

A comparison of the presumed signal peptide sequence of Slr1295 and Slr0513 of Synechocystis PCC 6803 (not shown) provided evidence that both proteins have a characteristic sequence motif in the $\mathrm{N}$-terminal region before the hydrophobic region [core sequence of $(\mathrm{S} / \mathrm{T})$ $\mathrm{R}-\mathrm{R}-\mathrm{x}-\mathrm{F}]$ that includes two consecutive and invariant arginine residues characteristic for the bacterial Tat (twwin-arginine translocation) system (Berks 1996; Berks et al., 2000). Bacterial Tat signal peptides are characterized by a high occurrence of a proline residue at position -6 to the signal peptidase cleavage site and of basic amino acids in the c-region. When analysing the $\mathrm{N}$-terminal amino acid region in the two proteins, it became apparent that Slr0513 meets all these criteria, while in Slr1295 the corresponding proline is missing and there is an acidic amino acid in the c-region before
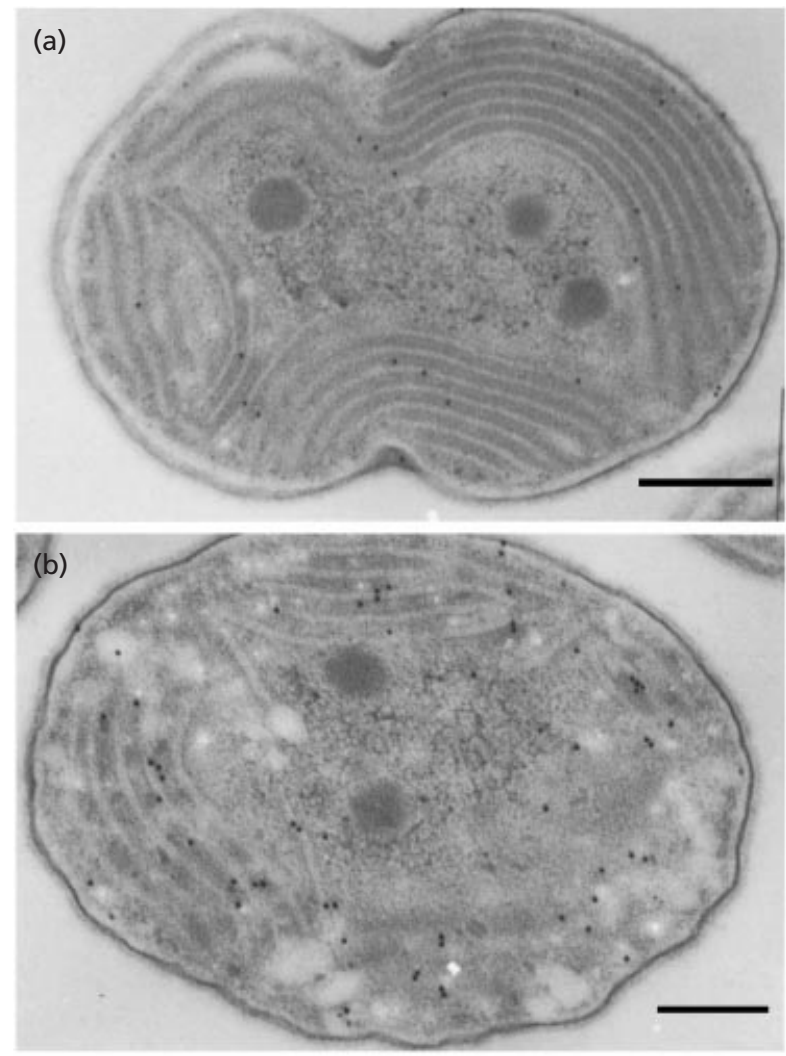

Fig. 11. Electron micrographs of Synechocystis PCC 6803 WT grown under iron-sufficient and iron-deficient conditions: immunocytochemical detection of SIr0513 by the anti-SIr0513 antiserum. (a) Synechocystis PCC 6803 cells cultivated for 2 days under iron-sufficient conditions and treated with the antiSlr0513 antiserum (dilution 1:100) in combination with goldlabelled anti-rabbit IgG (1:30). (b) Cells were grown for 2 days under iron-deficient conditions and treated as described for (a). Bars, $0.5 \mu \mathrm{m}$. Electron micrographs of cells grown for 2 days under iron-deficient conditions and treated with the corresponding pre-immune serum (1:100) in combination with goldlabelled anti-rabbit IgG showed hardly any gold labelling (not shown).

the signal peptidase cleavage site ('PSORT' prediction; von Heijne, 1986). Moreover, there is a possible additional cleavage site recognized by the program SignalP (Nielsen et al., 1999). This might be the reason why only significant amounts of Slr0513, but not of Slr1295, are found in the soluble protein fraction isolated from the periplasm. It has been shown that the ' $\Delta \mathrm{pH}$ dependent' protein import pathway of thylakoid membranes in plant chloroplasts and the bacterial Tat system are very closely related (Klösgen 1997; Brink et al., 1998; Wexler et al., 1998; Halbig et al., 1999). This might explain the high amounts of gold labels located intracellularly and suggests that Slr0513 is transported into the periplasm and also into the intrathylakoid space due to some misdirection. In contrast, Slr1295 does not seem to be exported in significant amounts into the periplasm (or lumen) - at least not under mild iron limitation and when $\operatorname{Slr} 0513$ is present. 


\section{Concluding remarks}

The intracellular localization and the co-purification of Slr1295 with PS II in Synechocystis PCC 6803 suggest a function for Slr1295 in protecting PS II under iron limitation. This is in agreement with the higher susceptibility of PS II for inactivation in the Slr1295-free mutant as compared to the WT. Thus, the function of Slr1295 in Synechocystis PCC 6803 is comparable to the suggested function of IdiA in Synechococcus PCC 6301/PCC 7942 (Michel et al., 1996; Exss-Sonne et al., 2000) and to some extent also to the function of a plant PS II-associated $22 \mathrm{Ku}$ heat-shock protein (Downs et al., 1999a, b). The cyanobacterial Slr1295 and IdiA, as well as the plant $22 \mathrm{Ku}$ protein, represent proteins that are not integral proteins of PS II, but function in protecting PS II under specific stress conditions. In the case of Slr1295 (and also IdiA), we suggest that PS II becomes protected or more effectively supplied with iron on the $\mathrm{D} 1 / \mathrm{D} 2$ reaction centre heterodimer $\left(\mathrm{Q}_{\mathrm{A}}-\mathrm{Fe}-\mathrm{Q}_{\mathrm{B}}\right)$. We think that it is highly likely that specific proteins exist to optimize PS II function under iron limitation since iron limitation is a commonly occurring nutrient limitation in natural habitats (see e.g. Geider \& La Roche, 1994; Behrenfeld \& Kolber, 1999). PS II has been proven to be the most labile reaction of the photosynthetic process, and the D1 (and also D2) polypeptide has an extraordinary high turnover under various environmental stresses (Aro et al., 1993; Ke, 2001), thus having an elevated iron requirement due to the PS II repair cycle. Based on our results, Slr1295 seems to be a good candidate for such an optimizing and protective function, since due to its assumed original function as a component of an iron transporter it is expressed in elevated amounts under iron limitation and can interact with iron. From an evolutionary point of view, Slr1295 seems to be a protein acquiring a different and/or additional function during evolution (for review see Murzin, 1993), but retaining significant homology to the protein family of its original function.

\section{ACKNOWLEDGEMENTS}

The financial support of the Deutsche Forschungsgemeinschaft is gratefully acknowledged. We thank Dr Sabine Fulda (Universität Rostock, LS Pflanzenphysiologie, Rostock, Germany) for providing the anti-Slr0513 antibody and Professor Klaus Peter Bader (Universität Bielefeld, Biologie VIII : Zellphysiologie, Bielefeld, Germany) for providing the antibodies against phycocyanin and allophycocyanin.

\section{REFERENCES}

Adhikari, P., Berish, S. A., Nowalk, A. J., Veraldi, K. L., Morse, S. A. \& Mietzner, T. A. (1996). The $f b p A B C$ locus of Neisseria gonorrhoeae functions in the periplasm-to-cytosol transport of iron. J Bacteriol 178, 2145-2149.

Angerer, A., Gaisser, S. \& Braun, V. (1990). Nucleotide sequences of the $s u f A, s f u B$, and $s f u C$ genes of Serratia marcescens suggest a periplasmic-binding-protein-dependent iron transport mechanism. J Bacteriol 172, 572-578.

Aro, E. M., Virgin, I. \& Andersson, B. (1993). Photoinhibition of photosystem II. Inactivation, protein damage and turnover. Biochim Biophys Acta 1143, 113-134.

Behrenfeld, M. J. \& Kolber, Z. S. (1999). Widespread iron limitation of phytoplankton in the South Pacific Ocean. Science 283, 840-843.

Berish, S. A., Mietzner, T. A., Mayer, L. W., Genco, C. A., Holloway, B. P. \& Morse, S. A. (1990a). Molecular cloning and characterization of the structural gene for the major ironregulated protein expressed by Neisseria gonorrhoeae. J Exp Med 171, 1535-1546.

Berish, S. A., Kapczynski, D. R. \& Morse, S. A. (1990b). Nucleotide sequence of the Fbp gene from Neisseria meningitidis. Nucleic Acids Res 18, 4596.

Berks, B. C. (1996). A common export pathway for proteins binding complex redox cofactors? Mol Microbiol 22, 393-404.

Berks, B. C., Sargent, F. \& Palmer, T. (2000). The Tat protein export pathway. Mol Microbiol 35, 260-274.

Bibby, T. S., Nield, J. \& Barber, J. (2001a). Iron deficiency induces the formation of an antenna ring around trimeric photosystem I in cyanobacteria. Nature 412, 743-745.

Bibby, T. S., Nield, J. \& Barber, J. (2001b). Three-dimensional model and characterization of the iron-stress-induced CP43'photosystem I supercomplex isolated from the cyanobacterium Synechocystis PCC 6803. J Biol Chem 276, 43246-43252.

Block, M. A. \& Grossman, A. R. (1988). Identification and purification of a derepressible alkaline phosphatase from Anacystis nidulans R2. Plant Physiol 86, 1179-1184.

Boekema, E. J., Hifney, A., Yakushevska, A. E., Piotrowski, M., Keegstra, W., Berry, S., Michel, K.-P., Pistorius, E. K. \& Kruip, J. (2001). A giant chlorophyll-protein complex induced by iron deficiency. Nature 412, 745-748.

Bradford, M. M. (1976). A rapid and sensitive method for the quantitation of microgram quantities of protein utilizing the principle of protein-dye binding. Anal Biochem 72, 248-254.

Brink, S., Bogsch, E. G., Edwards, W. R., Hynds, P. J. \& Robinson, C. (1998). Targeting of thylakoid proteins by the $\Delta \mathrm{pH}$-driven twin-arginine translocation pathway requires a specific signal in the hydrophobic domain in conjunction with the twin-arginine motif. FEBS Lett 434, 425-430.

Burnap, R., Koike, H., Sotiropoulou, G., Sherman, L. A. \& Inoue, Y. (1989). Oxygen evolving membranes and particles from the transformable cyanobacterium Synechocystis sp. PCC 6803. Photosynth Res 22, 123-130.

Burnap, R. L., Troyan, T. \& Sherman, L. A. (1993). The highly abundant chlorophyll-protein complex of iron-deficient Synechococcus sp. PCC $7942\left(\mathrm{CP}^{\prime} 3^{\prime}\right)$ is encoded by the isiA gene. Plant Physiol 103, 893-902.

Chang, A. C. Y. \& Cohen, S. N. (1978). Construction and characterization of amplifiable multicopy DNA cloning vehicles derived from the P15A cryptic miniplasmid. J Bacteriol 134, 1141-1156.

Downs, C. A., Coleman, J. S. \& Heckathorn, S. A. (1999a). The chloroplast $22-\mathrm{Ku}$ heat-shock protein: a lumenal protein that associates with the oxygen evolving complex and protects photosystem II during heat stress. J Plant Physiol 155, 477-487.

Downs, C. A., Ryan, S. L. \& Heckathorn, S. A. (1999b). The chloroplast small heat-shock protein: evidence for a general role in protecting photosystem II against oxidative stress and photoinhibition. J Plant Physiol 155, 488-496.

Engels, A., Kahmann, U., Ruppel, H. G. \& Pistorius, E. K. (1997). Isolation, partial characterization and localisation of a dihydrolipoamide dehydrogenase from the cyanobacterium Synechocystis PCC 6803. Biochim Biophys Acta 1340, 33-44. 
Exss-Sonne, P., Tölle, J., Bader, K. P., Pistorius, E. K. \& Michel, K.-P. (2000). The IdiA protein of Synechococcus sp. PCC 7942 functions in protecting the acceptor side of photosystem II under oxidative stress. Photosynth Res 63, 145-157.

Falk, S., Samson, G., Bruce, D., Huner, N. P. A. \& Laudenbach, D. E. (1995). Functional analysis of the iron-stress induced CP43' polypeptide of PS II in the cyanobacterium Synechococcus sp. PCC 7942. Photosynth Res 45, 51-60.

Ferreira, F. \& Straus, N. A. (1994). Iron deprivation in cyanobacteria. J Appl Phycol 6, 199-210.

Flores, E., Herrero, A. \& Guerrero, M. G. (1982). Production of ammonium dependent on basic L-amino acids by Anacystis nidulans. Arch Microbiol 131, 91-94.

Forng, R.-Y., Ekechukwu, C. R., Subbarao, S., Morse, S. A. \& Genco, C. A. (1997). Promoter mapping and transcriptional regulation of the iron-regulated Neisseria gonorrhoeae $f b p A$ gene. J Bacteriol 179, 3047-3052.

Fulda, S., Huang, F., Nilsson, F., Hagemann, M. \& Norling, B. (2000). Proteomics of Synechocystis sp. strain PCC 6803. Eur J Biochem 267, 5900-5907.

Geider, R. J. \& La Roche, J. (1994). The role of iron in phytoplankton photosynthesis, and the potential for ironlimitation of primary productivity in the sea. Photosynth Res 39, 275-301.

Grimme, L. H. \& Boardman, N. K. (1972). Photochemical activities of a particle fraction $\mathrm{P}_{1}$ obtained from the green alga Chlorella fusca. Biochem Biophys Res Commun 49, 1617-1620.

Halbig, D., Hou, B., Freudl, R., Sprenger, G. A. \& Klösgen, R. B. (1999). Bacterial proteins carrying twin- $R$ signal peptides are specifically targeted by the $\Delta \mathrm{pH}$-dependent transport machinery of the thylakoid membrane system. FEBS Lett 447, 95-98.

Kaneko, T., Sato, S., Kotani, H. \& 21 other authors (1996). Sequence analysis of the genome of the unicellular cyanobacterium Synechocystis sp. PCC 6803. II. Sequence determination of the entire genome and assignment of potential proteincoding regions. DNA Res 3, 109-136.

Katoh, H., Grossman, A. R., Hagino, N. \& Ogawa, T. (2000). A gene of Synechocystis sp. strain PCC 6803 encoding a novel iron transporter. J Bacteriol 182, 6523-6524.

Katoh, H., Hagino, N., Grossman, A. R. \& Ogawa, T. (2001a). Genes essential to iron transport in the cyanobacterium Synechocystis sp. strain PCC 6803. J Bacteriol 183, 2779-2784.

Katoh, H., Hagino, N. \& Ogawa, T. (2001b). Iron-binding activity of FutA1 subunit of an ABC-type iron transporter in the cyanobacterium Synechocystis sp. strain PCC 6803. Plant Cell Physiol 42, 823-827.

Ke, B. (2001). The primary electron donor of photosystem II, P680, and photoinhibition. In Photosynthesis, Photobiochemistry and Photobiophysics, Advances in Photosynthesis, Vol. 10, pp. 271-288, Dordrecht: Kluwer.

Kirby, S. D., Lainson, F. A., Donachie, W., Okabe, A., Tokuda, M., Hatase, O. \& Schryvers, A. B. (1998). The Pasteurella haemolytica $35 \mathrm{kDa}$ iron-regulated protein is an FbpA homologue. Microbiology 144, 3425-3436.

Klösgen, R. B. (1997). Protein transport into and across the thylakoid membrane. J Photochem Photobiol B: Biology 38, 1-9.

Laudenbach, D. E. \& Straus, N. A. (1988). Characterization of a cyanobacterial iron stress-induced gene similar to $p s b C$. J Bacteriol 170, 5018-5026.

Michel, K.-P. \& Pistorius, E. K. (1992). Isolation of a photosystem II associated $36 \mathrm{kDa}$ polypeptide and an iron-stress $34 \mathrm{kDa}$ polypeptide from thylakoid membranes of the cyanobacterium
Synechococcus PCC 6301 grown under mild iron deficiency. $Z$ Naturforsch 47c, 867-874.

Michel, K.-P., Thole, H. H. \& Pistorius, E. K. (1996). IdiA, a 34 kDa protein in the cyanobacteria Synechococcus sp. strains PCC 6301 and PCC 7942, is required for growth under iron and manganese limitations. Microbiology 142, 2635-2645.

Michel, K.-P., Exss-Sonne, P., Scholten-Beck, G., Kahmann, U., Ruppel, H. G. \& Pistorius, E. K. (1998). Immunocytochemical localisation of IdiA, a protein expressed under iron or manganese limitation in the mesophilic cyanobacterium Synechococcus PCC 6301 and the thermophilic cyanobacterium Synechococcus elongatus. Planta 205, 73-81.

Michel, K.-P., Krüger, F., Pühler, A. \& Pistorius, E. K. (1999). Molecular characterization of $i d i A$ and adjacent genes in the cyanobacteria Synechococcus sp. strains PCC 6301 and PCC 7942. Microbiology 145, 1473-1484.

Michel, K.-P., Pistorius, E. K. \& Golden, S. S. (2001). Unusual regulatory elements for iron deficiency induction of the $i d i A$ gene of Synechococcus elongatus PCC 7942. J Bacteriol 183, 50155024 .

Mietzner, T. A. \& Morse, S. A. (1994). The role of iron-binding proteins in the survival of pathogenic bacteria. Annu Rev Nutr 14, 471-493.

Murzin, A. G. (1993). Can homologous proteins evolve different enzymatic activities? Trends Biochem Sci 18, 403-405.

Nielsen, H., Brunak, S. \& von Heijne, G. (1999). Machine learning approaches for the prediction of signal peptides and other protein sorting signals. Protein Eng 12, 3-9.

Nierzwicki-Bauer, S. A., Balkwill, D. L. \& Stevens, S. E., Jr (1983). Three-dimensional ultrastructure of a unicellular cyanobacterium. J Cell Biol 97, 713-722.

Omata, T. \& Murata, N. (1984). Isolation and characterization of three types of membranes from the cyanobacterium (blue-green alga) Synechocystis PCC 6714. Arch Microbiol 139, 113-116.

Park, Y.-I., Sandström, S., Gustafsson, P. \& Öquist, G. (1999). Expression of the isiA gene is essential for the survival of the cyanobacterium Synechococcus sp. PCC 7942 by protecting photosystem II from excess light under iron limitation. Mol Microbiol 32, 123-129.

Sambrook, J., Fritsch, E. F. \& Maniatis, T. (1989). Molecular Cloning: a Laboratory Manual, 2nd edn. Cold Spring Harbor, NY : Cold Spring Harbor Laboratory.

Schäfer, A., Tauch, A., Jäger, W., Kalinowski, J., Thierbach, G. \& Pühler, A. (1994). Small mobilizable multi-purpose cloning vectors derived from the Escherichia coli plasmids pK18 and pK19: selection of defined deletions in the chromosome of Corynebacterium glutamicum. Gene 145, 69-73.

Smith, P. K., Krohn, R. I., Hermanson, G. T., Mallia, A. K., Gartner, F. H., Provenzano, M. D., Fujimoto, E. K., Goecke, N. M., Olson, B. J. \& Klenk, D. C. (1985). Measurement of protein using bicinchoninic acid. Anal Biochem 150, 76-85.

Stephan, D. P., Ruppel, H. G. \& Pistorius, E. K. (2000). Interrelation between cyanophycin synthesis, L-arginine catabolism and photosynthesis in the cyanobacterium Synechocystis sp. strain PCC 6803. Z Naturforsch 55c, 927-942.

Straus, N. A. (1994). Iron deprivation: physiology and gene regulation. In The Molecular Biology of Cyanobacteria, pp. 731-750. Edited by D. A. Bryant. Dordrecht: Kluwer.

Tam, R. \& Saier, M. H., Jr (1993). Structural, functional, and evolutionary relationships among extracellular solute-binding receptors of bacteria. Microbiol Rev 57, 320-346.

Tandeau de Marsac, N. \& Houmard, J. (1988). Complementary 
chromatic adaptation: physiological conditions and action spectra. Methods Enzymol 167, 318-328.

von Heijne, G. (1986). A new method for predicting signal sequence cleavage sites. Nucleic Acids Res 14, 4683-4690.

Webb, E. A., Moffett, J. W. \& Waterbury, J. B. (2001). Iron stress in open-ocean cyanobacteria (Synechococcus, Trichodesmium, and Crocosphaera spp.): identification of the IdiA protein. Appl Environ Microbiol 67, 5444-5452.

Wenk, S.-O. \& Kruip, J. (2000). Novel, rapid purification of the membrane protein photosystem I by high-performance liquid chromatography on porous materials. J Chromatogr B 737, 131-142.

Wexler, M., Bogsch, E. G., Klösgen, R. B., Palmer, T., Robinson, C.
\& Berks, B. C. (1998). Targeting signals for a bacterial Secindependent export system direct plant thylakoid import by the $\Delta \mathrm{pH}$ pathway. FEBS Lett 431, 339-342.

Williams, J. G. K. (1988). Construction of specific mutations in photosystem II photosynthetic reaction center by genetic engineering methods in Synechocystis PCC 6803. Methods Enzymol 167, 766-778.

Zak, E., Norling, B., Maitra, R., Huang, F., Andersson, B. \& Pakrasi, H. B. (2001). The initial steps of biogenesis of cyanobacterial photosystems occur in plasma membranes. Proc Natl Acad Sci US A 98, 13443-13448.

Received 4 April 2002; revised 24 June 2002; accepted 25 June 2002. 